\title{
Correction to: Criminal Anthroposcenes: Media and Crime in the Vanishing Arctic
}

\section{Correction to:}

A. Lam, M. Tegelberg, Criminal Anthroposcenes, Palgrave Studies in Crime, Media and Culture, https://doi.org/10.1007/978-3-030-46004-4

This book was inadvertently published with incorrect authorship for each chapter. This has now been updated in all the chapters. The co-authored chapters now mirror the cover authorship, where 'with' is used rather than 'and' (as in Anita Lam with Matthew Tegelberg).

The updated original online version for this chapter can be found at https://doi.org/10.1007/978-3-030-46004-4

(C) The Author(s) 2021 